\title{
HOW CRITICAL SPORT PEDAGOGY CONTRIBUTES TO PHYSICAL EDUCATION IN GERMANY
}

\author{
COMO A PEDAGOGIA CRÍTICA DO ESPORTE CONTRIBUI PARA A EDUCAÇÃO \\ FISICA NA ALEMANHA
}

COMO LA PEDAGOGÍA CRÍTICA DEL DEPORTE CONTRIBUYE PARA LA EDUCACIÓN FÍSICA EN ALEMANIA

Christian Gaum ${ }^{*}$

\begin{abstract}
Keywords:
Education.

Sports.

Social values.

Physical Education.

Abstract: The aim of this paper is to substantiate the educational potential of sport in PE programs at school and to explore how critical sport pedagogy can contribute to these programs. To this end, the main ideas behind critical-emancipatory movements in Germany over the past 40 years are investigated and outlined. Due to the absence of a holistic approach, the focus of the current concept of educative PE in Germany is twofold: to educate toward sport and to educate through sport. In line with this concept, sport in society needs to be addressed without simply being adopted as a model. Following these core assumptions, this paper puts forward the thesis that sport has the potential to empower children to deal with their increasingly complex and contingent lifeworlds, which is important when facing future challenges such as social issues and, thus, provides pedagogical legitimization of PE as a school subject.
\end{abstract}

Palavras chave: Educação.

Esportes.

Valores sociais.

Educação Física.

Palabras clave: Educación.

Deportes.

Valores sociales.

Educación Física.

Resumo: 0 objetivo desse artigo é evidenciar o potencial educacional do esporte em programas de Educação Física na escola e explorar como a pedagogia crítica do esporte pode contribuir para esses programas. Para este fim, as principais ideias pressupostas nos movimentos crítico-emancipatórios de Alemanha, nas últimas quatro décadas, são investigadas e delineadas. Graças à ausência de uma abordagem holística, o propósito atual de Educação Física na Alemanha é duplo: educar para o esporte e educar através do esporte. Segundo esse conceito, o esporte na sociedade precisa ser problematizado sem ser apenas assumido como um modelo. Conforme essas premissas centrais, esse texto trabalha com a tese de que o esporte tem o potencial de empoderar crianças para lidar com seus mundos cada vez mais complexos e contingentes, o que é importante para enfrentar os futuros desafios como uma questão social e, portanto, oferecer a legitimação pedagógica da Educação Física como matéria escolar.

Resumen: El objetivo de este artículo es evidenciar el potencial educacional del deporte en programas de Educación Física en la escuela y explorar como la pedagogía crítica del deporte puede contribuir a estos programas. Para este fin, las principales ideas presupuestas en los movimientos crítico-emancipatórios de Alemania en las últimas cuatro décadas son investigadas y delineadas. Debido a la ausencia de un abordaje holístico, el propósito del actual concepto de Educación Física educativa en Alemania es duplo: educar para el deporte y educar a través del deporte. Según este concepto, el deporte en la sociedad necesita ser problematizado sin ser solamente asumido como un modelo. De acuerdo con esas premisas centrales, este artículo trabaja con la tesis de que el deporte tiene el potencial de empoderar niños para tratar con sus mundos cada vez más complejos y contingentes, lo que es importante para enfrentar los futuros desafíos como una cuestión social y, por lo tanto, ofrecer legitimación pedagógica de la Educación Física como materia escolar.
*Institut für Sportwissenschaften, Abteilung Sportpädagogik . Frankfurt am Main. Germany. E-mail: gaum@ sport.uni-frankfurt.de

Received 05 May 2019

Accepted 04 September 2019 Published 16 November 2019

DOI: hitps://doi.org/10.22456/1982-8918.96229 (c) (1) (8) Licence 


\section{INTRODUCTION}

Critical pedagogy challenges its own theoretical premises and practical applications. This fact is of particular importance for the field of sport pedagogy, which has great practical relevance. Sport, as an object of sports science, can be understood as a pre-theoretical practice (CAYSA, 2006) that is devoid of critical thinking and, due to its practice-oriented functional logic, induces denial and rejection of what is unfamiliar. This practice with its overriding application orientation follows the logic that a theory is only as good as its potential for practical application; if there is no such potential, the theory must be regarded as lacking in practical relevance, rendering examination and discussion of its substance futile and unnecessary. Critical theory, however, unsettles the practice and does not aim to substantiate it by considering its usefulness. Consequently, effective practice and critical reflection appear to be incompatible. Following Heidegger (1984), it can be pointedly summarized: the science of sport does not think.

\section{HISTORICAL OUTLINE - EMANCIPATION AND CRITIQUE}

Sport educates, and sport promotes activity. It is with impressive and somewhat natural persistence that representatives of sports clubs and sports policy makers emphasize the social benefits of organized sport, which stem from its educational potential. Despite proclaimed selfevidence and the empirically proven facts that physical education (PE) is the most popular school subject in Germany (BRÄUTIGAM, 2013) and "German sports clubs have more than 27 million members making them the largest organization of the civil society in Germany" (HARTMANNTEWS, 2017, p. 9), sport has long been highly criticized in Germany. The consequences of the criticism of sport in general in the 1970s (RIGAUER, 1969) can still be discerned today both in theory and practice (KRÜGER, 2004). In this paper the ideas behind the negative attitude toward sport pedagogy are explored in order to provide a theoretically sound substantiation of the educational potential of sport as a school subject. Adorno's critical theory of society and his remarks on sport can be used as a starting point to substantiate the basic line of argumentation in this paper, in which the idealistic separation of the business world from the world of sport is made and the dialectical structure of sport as a school subject is investigated. In this way current contradictions of sport can be explored without trying to resolve them, and better understanding of these contradictions may be relevant for the design and development of PE programs.

"The rules of the game resemble those of the market, equal chances and fair play for all, but only as a struggle of all against all. Thus it is that sport permits competition, now reduced to a form of brutality, to survive in a world in which competition has actually been eliminated" (ADORNO, 1991, p. 90). Sport leads one to believe in fair competition. The world of capitalistic power structures, however, is deceptive, since sport per se is in no way fair. Rather, it is heavily permeated by the mechanisms of exploitation and cost-benefit calculations. Following Thornstein Veblen's analysis of society in The Theory of the Leisure Class, Adorno recognizes "[...] sport as pseudo-activity, as the channeling of energies which could otherwise become dangerous, as the endowing of meaningless activity with a speciousness and significance [...] It provides a common denominator for the conflicting desires to act purposefully and to waste time" (ADORNO, 1983, p. 79). The crux of the matter is that sport is not an end in itself; rather, it is work on the body to make the body fit for work. Sport becomes affirmative through rational and purposeful self-optimization and self-discipline; thus, it contributes to greater focus, 
concentration, productivity and social interaction. If this were fully correct, sport understood as merely a playful activity would have no potential, since the idealistic properties such as achievement, fairness, and a purpose-free character would be reversed in practice. Despite the seeming radicalness of this criticism, today's elite sport is a clear reflection of the wide gap between ideal and real. Manipulation, fraud, and instrumental rationality are forms of deviant behavior in organized sport, and in a dysfunctional system such behavior seems perfectly reasonable. To act in compliance with rules would, therefore, not be advantageous.

Sports events are "[...] tolerated excesses that combine cruelty and aggression with an authoritarian moment, the disciplined observance of rules" (ADORNO, 1983, p. 79). In Germany critical sports theory challenged this criticism only one-sidedly and in opposition to Adorno's dialectical approach. According to Adorno, sport is "ambiguous" and through fair play, chivalry, and consideration of the weak it even can appear to function anti-barbarically. However, Adorno also recognizes the dangerous potential of sport to stimulate aggression and brutality. The systematic analysis of such ambiguity is important. "Insofar as education exerts an influence over it, the results could be applied to the world of sport" (ADORNO, 2003, p. 681). This point has been taken into consideration in sport pedagogy because the assumption that sport develops its pedagogical potential more or less automatically cannot be maintained.

Three lines of argumentation influencing how contradictions in society are dealt with (GRUSCHKA, 2004, p. 48) can be identified and applied to critical sport pedagogy. First, affirmative acceptance of the current state as the presumed best possibility conflicts with Hume's law and extrapolates from is to ought. Sport is extremely popular, that's why sport is good! Second, the optimistic outlook of a better future indicates acceptance of the current state and therefore denial of a critical-constructive moment: Sport has educational potential, that's why everything is going to be just fine! Third, nihilistic withdrawal from current contradictions is justified by the belief that withdrawal is unavoidable due to the constitutive features of sport and that the opposite is an appropriate reaction: Nice guys finish last, and that's okay!

To not buy into the idea of affirmation, in critical sport pedagogy sport in society needs to be addressed without it simply being adopted as a model. Instead, the social parameters of sport should be identified as a way to exert pedagogical influence (BENNER, 2001), which would emphasize the educational potential of sport. In this way, the starting point of various didactic approaches in critical sport pedagogy is the individual and not the object of sport. Sport then could be examined and analyzed in terms of its potential for personality development, and it would cease to be regarded as a self-legitimizing valuable cultural good and thus as an important school subject. In the following, prominent approaches stemming from this position will be addressed in a brief summary of the history of sport pedagogy in Germany.

Prohl (2010) identifies various didactical concepts and subsumes them under the term critical-emancipatory movements. These concepts are based on the understanding that the pedagogical aim of PE is to support the development of individuals. The didactical concepts introduced hereinafter see the aim of sport pedagogy to be to challenge the various practices of the social phenomenon of sport and to determine whether these actually promote young people's development. The starting point of their analyses is, therefore, the subject of education and not the social phenomenon of sport. Reducing the pedagogical rationale for offering $\mathrm{PE}$ as a school subject to an educational qualification for taking part in extracurricular sport ignores the educational potential of PE for the development of individuality and personality. 
The critical-emancipatory movements endeavor to overcome an exclusive orientation along sport's structures of meaning and guidelines. A number of concepts can be identified, and their pedagogical rationale, didactic content, and corresponding teaching methods can be outlined. With these approaches new ideas have been introduced in the German specialist discourse although their significance for PE should not be overestimated, since they have been largely ignored in school curricula so far.

Against an explicitly emancipatory background, Ehni (1977) refers to the terms capacity to act and multiperspectivity when he presents his pedagogical rationale for PE as a school subject. He interprets these terms as follows:

The school with its commitment to the dimension of a general competence and capacity to act becomes an interpretative institution that seeks to represent social reality and its real as well as potential dimensions of meaning in the school curriculum. A multiperspective school education, quite simply, is understood to be the reconstruction of reality from different perspectives (EHNI, 1977, p. 108).

The emancipatory substance of Ehni's approach is reflected in the task of sport didactics, which he describes as the discussion of meaning (2000, p. 13): "Physical education classes should not be about the appropriate representations of traditional segments of the reality of sport, they should be about constituting new areas of meaning" (1977, p. 103). In PE, meaning not only is extracted, it is imparted and intersubjectively discussed. Developing the ability to perform various movements is not the focus of PE at school, as it is in sport in society. The reality of sport should be addressed but not with the intention of liberating students from it: "The teaching objective would be to effectively demonstrate sport to students in order to interpret it subsequently" (PROHL, 2010, p. 114). Following this line of argumentation, the meaning of sport in PE at school would have to be questioned and modified. Ehni argues that sport per se has no inherent meaning, but rather sport is constructivist and evolves in the process of action. This means that the meaning of sport derives from the individual engaged in doing sport, and there is no abstract meaning independent of the individual's interests. For this reason, teaching sport in society is just a starting point which then needs to be critically evaluated to "[...] create new meaning out of old meaning" (EHNI, 1977, p. 103).

Dietrich and Landau (1990) emphasize this critical attitude toward sport in their socialecological approach. They maintain that extracurricular sport is ill-suited as a didactic point of reference for PE as a school subject. They argue that extracurricular sport has little potential to counteract various social developments such as mediatization and loss of local space for physical movement. Put differently, for them sport provides insufficient solutions to social challenges in the lifeworlds of children and youths. PE classes in which the focus is learning various sports and physical skills are based on allegedly correct motion solutions. There is no room for a free and independent experience of movement although that would be necessary for the creation and development of one's own movement spaces. The choice of didactic content in PE programs at school is closely connected with the rationale of sport pedagogy which is not capable of adequately addressing technological change: "On the contrary, it runs the risk of further intensifying those questionable tendencies of a growing use of technology that have already permeated the world of sport" (DIETRICH; LANDAU, 1990, p. 12). The emancipatory dimension of the approach becomes apparent in the fact that the creation of child-fair movement situations is artificial. While Ehni focuses on the type of sport that learners know from their everyday world, Dietrich and Landau argue that the principles and guidelines of sport cannot 
simply be adopted; instead the content to be learned should be derived from those tendencies of modern industrial society that are relevant to the learners' lifeworlds. A characteristic component of this socio-critical position is the belief that the specialized teaching that takes place in schools is not suitable for an emancipatory education, which is why it is deemed necessary to expand sport pedagogy to reach into the lifeworlds of students.

In terms of methodological implementation, that is, how the content of teaching concepts can be incorporated in PE programs at school, critical sport pedagogy endorses the concept of open PE (HILDEBRAND; LAGING, 1981; FRANKFURTER ARBEITSGRUPPE, 1982). Open PE opposes teacher-centered PE geared toward various sport disciplines; rather, it promotes student-centered learning through a variety of physical activities ${ }^{1}$ that go beyond typical understanding of sport activities. An essential connection between open PE and the socioecological approach becomes apparent although the rationale behind the content to be taught is more a reflection of the educational concept which sees education coming from the experience of one's material and social environment in relation to one's own body, than it is a reflection of the lifeworlds of young people. Funke uses the term body experience $(1987$, p. 99) to describe, for example, the change from tension to relaxation or the perception of the functioning of the inner organs such as heart rate and breathing. The body serves as a facilitator allowing the individual to experience his or her material and social environment. A recent overview of the perspectives and challenges of using this term can be found in a study by Döhring (2013), who makes it clear that the idealized concept of completely open teaching cannot be implemented by school teachers. On the surface, this has to do with the paradoxical structure of school as an institution, the focus of which must be both the education of students by means of selection measures and the development of students' autonomous, self-determined personality. This, in turn, creates conflict between societal demands and individual interests, and it affects practices in PE. In relation to the basic paradox of all pedagogical actions caught between other-directedness and self-determination, it becomes obvious that the critical-emancipatory approaches not only emphasize the development of independence of young people, their ability to act independently is, as a matter of fact, presupposed. Funke (1989) discusses self-education. At this point, the critical-emancipatory movements, notwithstanding their own claim, run the risk of being incongruous with the lifeworlds of the learners since in pedagogical interactions a symmetrical relationship between teacher and student cannot be assumed. Further, rejection of sport in society as students know it could lead to the idea that an alternative world of PE exists.

Thetension hintedatinthe paragraph abovedrasticallyincreasesinthe instrumentalization controversy. Two polarizing orientations can be identified that seem to be incompatible: In one, sport as a cultural asset is believed to have educational potential (i.e., purpose, inherent logic, etc.); in the other, that specific educational potential is projected onto sport from the outside. Advocates of the first position assume that active exploration and discussion of sport results in sport being highly beneficial for personal development. For this, however, it is vital to fight against "[...] the programmatic appropriation of sport for all kinds of purposes [. . .] that cannot actually be deduced from sport's inherent structure" (SCHALLER, 1992, p. 11). According to this view, sport is a valuable part of the movement culture, and it should not be used to suit just any purpose (e.g., health, social education, etc.). Instrumentalization of this sort could lead to

\footnotetext{
1 Juggling, meditation, and physical dramatic arts exercises, for example, can be done in PE class at school. It is the Zeitgeist that provides the pedagogical legitimization for such activities. Expanding the content of curricular programs allows for more flexibility so that traditional sport education can be modified (e.g., beach volleyball, streetball), new sports (e.g., parkour, inline skating) included, and a stronger relationship to the interests and the lifeworlds of young people established.
} 
abuse; the physical fitness programs in Nazi Germany as well as the PE concepts in the former German Democratic Republic may serve as historical examples of sport that led to inhumane practices. From another perspective, it has been denied that sport has no meaning independent of time and culture. "Instead, sport has to be understood as a time-dependent system of movement behavior representing social values" (BECKERS, 1993, p. 227). Beckers rejects the idea of a pure and genuine sport. He argues that with a view to educational processes such an understanding might even be called irresponsible because it would render pedagogically legitimized decisions about the objectives and content of PE classes dispensable. The danger of affirmative tendencies to arise becomes apparent if either the individual or the object is subjected to instrumentalization.

\title{
3 PE IN GERMANY TODAY
}

The educational-theoretical controversy can be settled by acknowledging the fact that exclusive focus neither on the object (material) nor on the individual (formal) would meet the requirements of current critical sport pedagogy.

\begin{abstract}
The dispute between the two opposing parties regarding the precedence of either a formal or a material determination of the tasks of pedagogical practice will actually lead nowhere. It is not possible to argue that something like an individual's basic forces which exist independently of the acquisition of material world contents and which develop and are practiced only when the clash with those contents actually exist in an ontological sense. But it is also not possible to identify material contents that as educational contents possess a direct relevance in terms of meaning and purpose for the sport pedagogical practice (BENNER, 2001, p. 151).
\end{abstract}

For this reason, Benner suggests taking into consideration societal needs, which should be determined through regular and thorough investigation so that the pedagogical premises of PE programs are relevant for the learners. However, he maintains that an individual's selfcultivation ${ }^{2}$ is both the goal and essence of "Bildung", and it needs pedagogical intervention (external encouragement). With a view to sport in society, this means self-cultivation should be an aim of PE programs at school. Sport activities alone do not automatically fulfill the educational potential of PE; therefore, it is essential to take a critical approach to PE and so as to avoid duplication of a competitive club sport in the school curriculum. It can be concluded that the pedagogical aims of PE programs at school should be kept in mind when analyzing critically and constructively historical and current developments of the movement culture, to which sport belongs. "As part of this rationale, I suggest that emancipation, empowerment and critique are three key dimensions of critical pedagogy which are embedded in and constitutive of the practice of sport" (KIRK, 2006, p. 257).

Based on Benner's premises (2001, p. 128) of the pedagogical transformation of societal influences and the influence of a summons for self-activity, the concept of educative PE (PROHL, 2010) can be derived, which centres the dual task of education toward sport (movement-oriented) and education through sport (personality-oriented).

In a seminal essay on sport pedagogy in Germany, Klafki emphasized the importance of physical activity for education. Developing one's personality involves "[...] the development of a pleasurable and playful treatment and awareness of one's own body" (2001, p. 22). Education

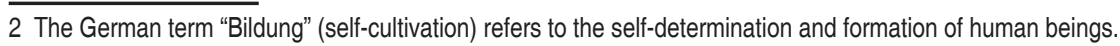


toward sport is therefore geared toward the potential experience of the movement culture, and it aims to show children and youths various kinds of positive experiences they can have through cultivating their movements. To achieve this, the challenges of movement tasks in sport contexts need to be addressed. A rationale founded on Klafkis philosophy of education for the content of a sport program should be to allow children and youths to experience, a feeling of completeness and at the same time should be relevant with a view to future challenges. This understanding of educational sport requires focus to go beyond the present to the long-term examination of challenges of physical movements. That what is familiar needs to be broadened in a way that challenges effective ways of dealing with movement-related issues. The focus of current didactic methods is to activate learning processes that, ultimately, facilitate self-activity within the scope of movement processes. Dealing with something new and unfamiliar is considered necessary for self-activity (PROHL, 2010). The reward for individuals is not to be found in the intended result (i.e., the ability to perform various movements successfully) but rather in experiencing the means taken to reach the aim (generally the movement actions) gaining in value to the extent where achieving the aim of the action is unpredictable. Seel (1995) called this aesthetic value of actions in sport "a celebration of inability."

The aesthetic ${ }^{3}$ core of $P E$ - in the way in which it is taught in a democratic society whose values it conveys - has been outlined. The goal of educative PE is to help students develop their personalities by teaching them key methods for acquiring important life skills through sport. Orientation toward Klafki's concept of general education serves as a common basis, irrespective of different curricular conceptualizations, which are fundamental in a pluralistic society. His criteria for "self-determination, co-determination, and solidarity" (2001, p. 21) are included in the dual task of educative PE by emphasizing education through sport. Klafki understands education to be the development of a combination of three basic skills:

- self-determination: individuals are able to make decisions regarding personal issues such as relationships and activities and to interpret inter-personal, professional, socio-political, ethnical, religious, and leisure-related (in this context, movement practice) matters;

- codetermination: individuals can (and should be given the opportunity) to shape conjoint cultural, ecological, social, and political conditions and circumstances; they have not only the right, but also the obligation to shape the living circumstances in their society; and

- solidarity: individuals demand the right to make choices and have a say in the decisionmaking process, which inevitably is bound to the recognition of others' rights to these, and they stand up for those who do not have the opportunity to practice self-determination or co-determination due to social circumstances such as underprivileged social status, political restrictions, or suppression.

The three aforementioned abilities involve emancipation, empowerment, and critique. Klafki's basic skills are considered indispensable prerequisites for active participation in a democratization process that should advance further. "A democracy is more than a form of government; it is primarily a mode of associated living, of conjoint communicated experience" (DEWEY, 1916, p. 67).

Overall, the focus of educative PE is both learning outcomes (education toward sport) and personal development (education through sport); it thus combines the two starting points of the instrumentalization controversy. Sport as part of the movement culture does, indeed, 
have educational potential, but it is not timeless or static; in a social context, sport as a cultural movement practice is subjected to transformation processes and is changeable. This raises the question of future challenges and didactic implementation.

\section{THE EDUCATIONAL POTENTIAL OF CRITICAL SPORT PEDAGOGY}

To determine the educational potential of critical sport pedagogy one must take into account current social developments and challenges students face in their lifeworlds, which are becoming increasingly unpredictable (LUHMANN, 1992; MAROTZKI, 1990).To cope with this contingency an individual needs to be able to deal with uncertainty and contradictions. In recognizing the dialectical structure of sport, its educational potential can be substantiated at two levels and between the poles of individual and society. The sport ideal is contrasted with sport critique to present, by way of synthesis and in accordance with the dialectical structure, a rationale for the educational potential of sport. The focus is on the level of social practice and the aim is to investigate the contribution to an educational physical education. The argumentation based on education theory is oriented toward the criteria of the significance of present and future. It is necessary to proceed in this way because otherwise one would fall behind the vanquished dualistic division in material justifications for the ontologically fixed intrinsic value of sport versus formal justifications for object-free subjective forces.

Representatives of organized sport often emphasize the societal benefit of sport, although empirical evidence to support this claim is scarce. The idealization of the educational potential of sport is inevitably connected with the hope that such potential can be developed and then the corresponding character-forming effects will occur.

Sport can teach values such as fairness, teambuilding, equality, discipline, inclusion, perseverance and respect. Sport has the power to provide a universal framework for learning values, thus contributing to the development of soft skills needed for responsible citizenship" (UNESCO, 2019a); "Sport is a powerful tool to strengthen social ties and networks, and to promote ideals of peace, fraternity, solidarity, non-violence, tolerance and justice (UNESCO, 2019b).

These examples evoke the principles of Coubertin's Olympic education and they still are regarded as fundamental principles of Olympism to this day. "The goal of the Olympic Movement is to contribute to building a peaceful and better world by educating youth through sport practiced without discrimination of any kind and in the Olympic spirit, which requires mutual understanding with a spirit of friendship, solidarity and fair play" (IOC, 2018, p. 11). Sport's educational contribution is intrinsically linked to an understanding of the essence of democracy which not only points to the values of social co-existence (education through sport), but also ascribes to this same movement culture a potential to reduce social inequities. For society, sport fulfills a socializing and integrative function, as a central principle of club sport is that its social significance derives from its integrative capacity and strong emphasis on fairness (GRUPE, 2000). Still, the logic of action in sport competitions very often follows a morale that makes success into an absolute, where the end justifies the means (GAUM, 2017). Baseball coach Leo Durocher gets to the heart of the matter when he claims that "nice guys finish last." With respect to $\mathrm{PE}$, this moral discrepancy has had the effect that the critical-emancipatory movements in the field of sport pedagogy question the educational legitimacy of extracurricular sport due to its competitive and performance-centered character. 
The rationale for this type of sport critique, however, stays tied to a way of thinking in which sport is not pedagogically suitable due the gap between the ideal and the real, that is, theory and practice. Its potential cannot freely unfold because both optimism as well as fatalism remain blind and negate a critical-constructivist approach. In both cases, the ambiguity of sport is obscured, though it should be dealt with, which makes Adorno's critique enlightening. Adorno understands sport as part of mass culture; mass culture would like to turn the consumers of sport into hooting spectators on the grandstands:

In so far as mass culture reflects the totality of life as a complete system of open or covert sportive competitive struggles, it enthrones sport as life itself and even eliminates the tension between sport on the Sunday day off and the wretchedness of the working week, a tension in which the better part of sport used to consist (ADORNO, 1991, p. 90).

Sport justifies social struggle, makes social inequality bearable, and allows belief in fairness and legitimacy of social and political power structures. Sport, therefore, is suitable for appeasing any critical tendency.

It is those attempts to appease geared toward making contradictions bearable that need to be discussed. First, the attempts to appease should be recognized and then actively addressed (emancipation) in order to change and stimulate democratization processes (empowerment). A culturally shaped world can be changed by people (GISSEL, 2019, p. 40). Thus, the educational potential does not lie in identifying key problems and subsequently adapting to requirements. Contingency (the tension between ideals and reality) should not be dispelled; rather, it should be accepted and dealt with in a constructive way, as this is the only way to deal with such conflicts critically. Dissolving the tension inevitably will result in a one-sided reduction. Examination of the dialectic (of the tension) is both reason and requirement for education. The educational potential is foundin the ambivalence. For Haut (2010), the potential of sport lies in the ideal desire for fair competition. The fact that sport does not fully conform to this ideal does not result in the absence of potential as can be seen precisely in people's desire for "a better practice" which is transferred onto sport. The question now arises as to why society is not as sportive as the ideal it celebrates (HAUT, 2010, p. 233).

What is the significance of a competent dealing with contingency for future challenges? Contingency develops significance for an aesthetic quality experience in the present and it is an indispensable prerequisite for a responsible and mature life in the future. Freedom and democracy, responsibility and maturity are possible only within the context of a productive and respectful handling of contingency, with tensions in the individual pursuit of happiness and social responsibility. In PE, sport, due to its dialectical structure, offers tension-based situations that can be dealt with productively and turned into positive experiences. In sport competitions one's action is oriented toward winning (thesis); however, the opponent is given the same chance at victory (antithesis). This leads to uncertainty, and uncertainty in action as a premise for the pleasure of the game (synthesis). "The common pleasure of the game, with respect to which the players are in absolute accord, is, to be sure, a pleasure which arises from each player attempting to defeat the other" (SUITS, 2014, p. 78). In other words, contingency enables quality experiences and unfolds contemporary relevance. The goal is "future-oriented educational work," that not only "reacts to social and cultural circumstances and processes, but that also helps to shape them under pedagogical responsibility" (KLAFKI, 2001, p. 19). This means teachers have the creative task of mediating didactical action, something that can be 
successful only when the process is not a means to an end, but rather regarded as valuable itself. A distortion of sport in PE (e.g. team contribution, rule changes) does not happen for its own sake; it could be done to enhance its educational potential. This is the playful dealing with uncertainty that arises from culture as a voluntary and self-imposed difficulty (GRUPE, 1982).

A future task of a critical sport pedagogy is to clarify and evaluate the relationship between pedagogical theory and pedagogical practice. To do this, it first is necessary to understand the lifeworlds of children and youths and then to identify the conditions and challenges of education in a movement culture. Benner's (2001) first principle, the transfer of social parameters into pedagogical influence, points to the critical and thoughtful adoption of social parameters under the pedagogical premise of making them useful for the individual. This is followed by the shaping and transforming of sportive practices so that their critical function is joined by a constructive function. Consequently, the present paper is also oriented toward Benner's (2001) second principle, to influence a summons to self-activity, according to which education is non-affirmative and legitimized due to its contribution to the development of selfdetermination, co-determination, and solidarity. "An individual learns to understand only when the understanding is the personal achievement of the learner and he or she perceives it that way. Responsibility and maturity allow the learner to evaluate and criticize" (GRUSCHKA, 2011, p. 185). The goal of education is maturity, and maturity can be reached only through self-active learning combined with external influence in the form of encouragement. External influence alone cannot lead to maturity. As Rousseau stated, it is vital to decide "whether you are to form the man or a citizen; for you cannot do both" (1991, p. 12). In other words, it is not possible to influence self-determination and formation ("Bildung") by education directly.

\section{REFERENCES}

ADORNO, Theodor W. Der Instrumentalisierungsvorwurf. Ende des Nachdenkens oder Alibi für die eigene Position? Sportwissenschaft, v. 23, n. 3, p. 233-258, 1993.

ADORNO, Theodor W. Kulturkritik und Gesellschaft I und II. Frankfurt am Main: Suhrkamp, 2003.

ADORNO, Theodor W. Prisms. Salt Lake City: MIT Press paperback ed., 1983.

ADORNO, Theodor W. The Culture Industry. Selected essays on mass culture. London and New York: Routhledge, 1991.

BENNER, Dietrich. Allgemeine Pädagogik. Eine systematisch-problemgeschichtliche Einführung in die Grundstruktur pädagogischen Denkens und Handelns. 4. ed. Weinheim: Juventa, 2001.

BRÄUTIGAM, Michael. Schülerforschung. In: BALZ, Eckard; BRÄUTIGAM, Michael; MIETLING, Wolf-Dietrich; WORLTERS, Petra. Empirie des Schulsports. 2. ed. Aachen: Meyer \& Meyer, 2013. p. 65-94.

CAYSA, Volker. Körperutopien. Eine philosophische Anthropologie des Sports. Frankfurt: Campus, 2006. 
DEWEY, John. Democracy and education (Open Access Resource). Champaign: Project Gutenberg. 1916. (EBSCO host eBook Collection).

DIETRICH, Knut; LANDAU, Gerhard. Sportpädagogik. Grundlagen, Positionen, Tendenzen. Reinbeck: Rohwolt, 1990.

EHNI, Horst. Sport und Schulsport. Didaktische Analysen und Beispiele aus der schulischen Praxis. Schorndorf: Hofmann, 1977.

EHNI, Horst. Vom Sinn des Schulsports. In: WOLTERS, Petra; EHNI, Horst; KRETSCHMER, Jürgen; SCHERLER, Karlheinz. Didaktik des Schulsports. Schorndorf: Hofmann, 2000. p. 9-35.

FRANKFURTER ARBEITSGRUPPE. Offener Sportunterricht - analysieren und planen. Reinbek: Rohwolt, 1982.

FUNKE, Jürgen. Sich-Bewegen als ästhetische Selbsterziehung - ein anthropologisches Bewegungsverständnis als Grundlage einer Turndidaktik. Lehrhilfen für den Sportunterricht, v. 12, p. 177-183, 1989.

FUNKE, Jürgen. Über den didaktischen Ansatz der „Körpererfahrung“. In: PEPER, Dieter; CHRISTMANN, Erich (Hrsg.). Zur Standortbestimmung der Sportpädagogik. Schorndorf: Hofmann, 1987. p. 94-108.

GAUM, Christian. Fairnessverständnis im Amateurfußball - Empirische Untersuchung auf Grundlage eines mehrdimensionalen Fairnessbegriffs. The German Journal of Exercise and Sport Research, v. 47, n. 4, p 348-359, 2017.

GISSEL, Norbert. Kritisch-Konstruktive Sportpädagogik: Studien zur Bildungstheorie und Didaktik des Sports. Baltmannsweiler: Schneider, 2019.

GRUPE, Ommo. Bewegung, Spiel und Leistung im Sport: Grundthemen der Sportanthropologie. Schorndorf: Hofmann, 1982.

GRUPE, Ommo. Vom Sinn des Sports. Schorndorf: Hofmann, 2000.

GRUSCHKA, Andreas. Negative Pädagogik: Einführung in die Pädagogik mit Kritischer Theorie. Wetzlar: Büchse der Pandora, 2004.

GRUSCHKA, Andreas. Verstehen lehren - Ein Plädoyer für guten Unterricht. Ditzingen: Reclam, 2011.

HARTMANN-TEWS, Ilse. Sportverbände und -vereine als Akteure der Zivilgesellschaft. In: DOSB. Sport ist fair. Remshalden: Wacker, 2017. p. 7-18.

HAUT, Jan. Was Sport über Gesellschaft verrät“. Perspektiven mit Elias, Bourdieu und Adorno. In: ADAM, Holger; AYDIN, Yasar; CETIN, Zülfukar; DOYMUS, Mustafa; ENGELMANN, Jonas; HENNING, Astrid; WITTE, Sonja. Pop Kultur Diskurs. Zum Verhältnis von Gesellschaft, Kulturindustrie und Wissenschaft. Mainz: Ventil, 2010. p. 219-236.

HEIDEGGER, Martin. Was heißt denken? Tübingen: Max Niemeyer, 1984.

IOC. Olympic Charter. Lausanne: DidWeDo, 2018.

KIRK, David. Sport Education, Critical Pedagogy, and Learning Theory: Toward an intrinsic Justification for Physical Education and Youth Sport. Quest, v. 58, p. 255-264, 2006. 
KLAFKI, Wolfgang. Bewegungskompetenz als Bildungsdimension. In: PROHL, Robert. Bildung und Bewegung. Hamburg. Czwalina, 2001. p. 19-28.

KRÜGER, Michael. Adorno, der Sport und die Kritische Sporttheorie. Sportwissenschaft, v. 34, n. 1, p. 21-32, 2004.

LUHMANN, Niklas. Kontingenz als Eigenwert in der modernen Gesellschaft. In: LUHMANN, Niklas. Beobachtungen der Moderne . Wiesbaden: Springer, 1992. p. 93-128.

MAROTZKI, Winfried. Entwurf einer strukturalen Bildungstheorie. Weinheim: DSV, 1990.

PROHL, Robert. Grundriss der Sportpädagogik. 3. ed. Wiebelsheim: Limpert, 2010.

RIGAUER, Bero. Sport und Arbeit. Soziologische Zusammenhänge und ideologische Implikationen. Frankfurt am Main: Suhrkamp, 1969.

ROUSSEAU, Jean-Jacques. Emilé oder über die Erziehung. 10. ed. Paderborn: Schöningh, 1991.

SCHALLER, Hans-Jürgen. Instrumentelle Tendenzen in der Sportpädagogik.

Sportwissenschaft, v. 22, n. 1, p. 9-31, 1992.

SEEL, Martin. Zelebration des Unvermögens. In: GERHARDT, Volker; WIRKUS, Bernd. Sport und Ästhetik. Köln: Academia, 1995. p. 113-125.

SUITS, Bernard. The grasshopper: Games, life and utopia. 3. ed. Peterborough: Broadview, 2014.

UNESCO .Value Education through Sport. 2019a. Disponível em: http://www.unesco.org/new/ en/social-and-human-sciences/themes/physical-education-and-sport/values-education-through-sport/ Acesso em: 12 jul. 2019.

UNESCO. Sport for Peace and Development. 2019b. Disponível em: http://www.unesco. org/new/en/social-and-human-sciences/themes/physical-education-and-sport/sport-for-peace-anddevelopment/Acesso em: 12 jul. 2019. 